\title{
Investigation on the Incidence, Diagnostic, Possibilities and Design of Prophylactic Treatment in an Outbreak of Bacterial Haemorrhagic Septicemia of Carp
}

\author{
Daniela LADOSI ${ }^{1 *}$, Octavian NEGREA ${ }^{1}$, Zamfir MARCHIS ${ }^{1}$, Flore CHIRILA ${ }^{1}$, Ana Maria Theodora \\ PARASCA ${ }^{1}$ \\ ${ }^{1}$ Faculty of Animal Science and Biotechnologies, University of Agricultural Sciences and Veterinary \\ Medicine Cluj-Napoca, Romania \\ * corresponding author: daniela.ladosi@usamvcluj.ro
}

Bulletin UASVM Animal Science and Biotechnologies 74(1)/ 2017

Print ISSN 1843-5262; Electronic ISSN 1843-536X

DOI:10.15835/buasvmcn-asb: 12168

\begin{abstract}
The investigations carried out on a sample of 53 breeders ( 31 females and 22 males),in the aquaculture farming system ofSuatu village, County of Cluj, concerning the incidence of bacterial hemorrhagicsepticaemia, its diagnosis and prophylactico-therapeutic possibilities. The results highlights an incidence of bacteriosis differentiated according to the category of breeders, $54.8 \%$ in females and36.3\% in males. Necropsy examination carried out on 3 specimens of suspected bacteriosis, highlights the presence of hemorrhagic skin lesions, which are dotted or diffuse, respectivelymusculo-cutaneous necrosis and ulcers. Regardingthe internal injuries, opening of the body cavity, revealedconsistency changes and septicemy form in major internal organs, as well as the presence of a sanguinolent appearence liquid.The bacterioscopic examination of smears from the pathologic material (skin surface and internal samples) colored with the Gram method, reveled bacterial microflora, represented by coccobacillus and straight bacilli or slightly curved, both Gram negative. Furthermore, the bacteriological (culture) examination performedon usual and selective culture mediae, distinguish the isolation of pure culture bacteriae belonging to the genus Aeromonas. The exam of biochemical traits, with the aid of API 20 E multitest determines that the isolated strains of Aeromonas spp. belong to the species Aeromonas hydrophila, indicted in the emergence and evolution of the bacterial of haemorrhagic septicaemia.Testing strains sensitivity to antibiotics and chemotherapy (through antibiograma level), reflects the isolated bacteria's values of sensitivity in decreasing order: amoxicillin, oxytetracycline, florfenicoland enrofloxacilin.However, reduced sensitivity was recorded to tetracycline and ampicillin and resistance to erythromycin.
\end{abstract}

Keywords: carp, diagnosis, investigations, prophylactic treatment

\section{INTRODUCTION}

As previously stated, the term of bacterial hemorrhagic septicemia was already discovered since 1933 (Snieszko and Bullock, 1976) and it is known by various synonyms such as red-mouth disease, infectious dropsy, rubella disease or redpest. The disease was described by several authors since then (Bohai etal., 1993, Joseph and Carnahan, 1994, Austin and Austin, 2007) and considered as opportunistic pathogens. The same pattern was found as well in Romanian lakes affecting carp breeders (Bud et al., 2001, Dăscălescu and Costea, 1995, Negrea, 2007). The aim of the investigations was to assess the incidence, the possibilities of 
diagnostic and design of prophylactictreatment in the case of an outbreak of bacterial hemorrhagic septicemia in carp breeders, raised in a traditional system. Thus, the focused on the incidence of the disease based on the clinical diagnosis and laboratory techniques for the pathogen detection and also on the prophylactic and therapeutic conduct which can be applied in the outbreak.

\section{MATERIALS AND METHODS}

Investigations were conducted in Cluj county, in an aquaculture farming system from Suatu, specialized in raising carp in an extensive manner, on a group of 53 breeders (31 females and 22 males).The aquaculture farming system has a total surface of 50 ha and it is structured in 3 lakes: Suatu, with a surface of 30 ha, Bercheș with a surface of 12 ha and Aruncuta with a surface of 8 ha. Among the existing species we can mention the common carp (Cyprinus carpio) crucian carp (Carassius gibelio) and other species such as the rudd (Scardinius erythrophtalmus) and the roach (Rutilus rutilus), etc.

Among the breeders diagnosed with anatomic and clinical lesions with external bleeding, a number of 3 were badly affected. On these samples bacterioscopic and bacteriological examinations were performed, in order to clearly establish etiological diagnosis, within the laboratories belonging to the Ihtiopathology Department, Faculty of Animal Science and Biotechnologies, Cluj Napoca.

\section{RESULTS AND DISSCUSIONS}

The results of the investigations carried out on 53 breeders ( 31 females and 22 males), reveals that the incidence of the bacterial hemorrhagic septicemia occures differently based on gender (Table 1).

In this breeders group it seems that the incidence of the disease is higher in the female breeders (54.8\%) compared to the values in the male breeders at $36.3 \%$. Same results are visually highlighted in Fig.1.

The morphopathology examinations at skin and visceral levels, reveals the presence of numerous bleeding spots at the base of the fins and on the body surface as well. Same evolution of the infections were described previously by Austin B. and Austin D.A. in 2007, on other freshwather fish. As a result of thehaemorrhagic necrotic processes, the tissue necrosis occures after a period of time.

Tab.1. The incidence of the bacterial hemorrhagic septicemia of carp

\begin{tabular}{ccccc}
\hline No. & Breeder group & No. & Positive & Positive $\%$ \\
\hline 1 & Females & 31 & 17 & 54,8 \\
\hline 2 & Males & 22 & 8 & 36,3 \\
\hline Total & & 53 & 25 & 47,1 \\
\hline
\end{tabular}

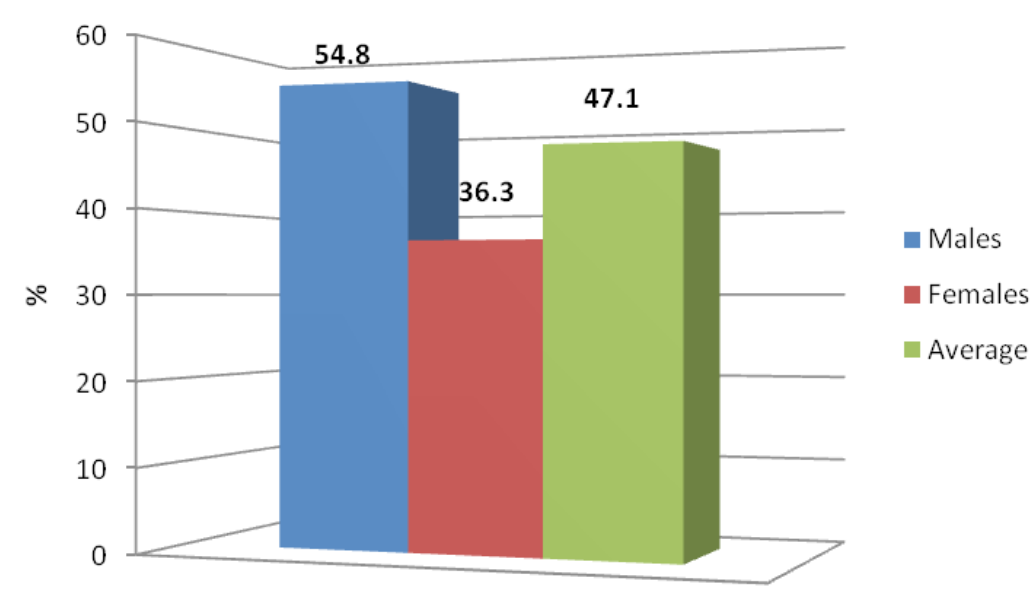

Fig. 1. SHB incidence variation based on gender 
This was noticed as white-gray color spots which favours limitation and detachment with the emmergence of ulcerative lesions. This status can evolve and affect the muscles as well. It should be noted the fact that these ulcerative traumasare facilitating the invasion and fast development of pathogenic fungus from Saprolegnia genus. There are visible as well other areas of necrosis, more or less spreaded at the level of the fins, including the caudal one. Beside the external lesions, during necropsy, we noticed haemorrhagic and/ orhaemorrhagic- necrotic changes at the level of the internal organs, with the presence of a serosanguineous liquidin the body cavity, in organs such asspleen, kidney, liver, both increased in volumeand the presence of yellowish gray outbreaks (necrotic processes).

The bacterioscopic examination of the smears made on the pathological samplesharvested from the level of the skin lesions and stained by the
Gram method - described by Dăscălescu P, Costea M (1995) - highlights in the microscopic field (ob.100x) bacterial microflora, represented by the cocobacilli and straight or slightly curved bacilli, Gram-negative.

The bacteriological examination (cultured samples) conducted on the pathological samples harvested from three breeders severely affected, performed on culture mediums (broth agar, blood agar)allowed the isolation of a pure culture of micro-organisms of the genus Aeromonas.

Following the examination of the biochemical samples with a API 20 E multitest system we encountered the following positive reactions to: ADH, INDOL, GELATINAZA, GLU, MAN,SAC, AMY, ARA, on the tested strains.

The results of the biochemical samples obtained after the usage of the API 20 E multitest showed that the isolated strains of Aeromonas spp. belong to the Aeromonas hydrophilaspecies,

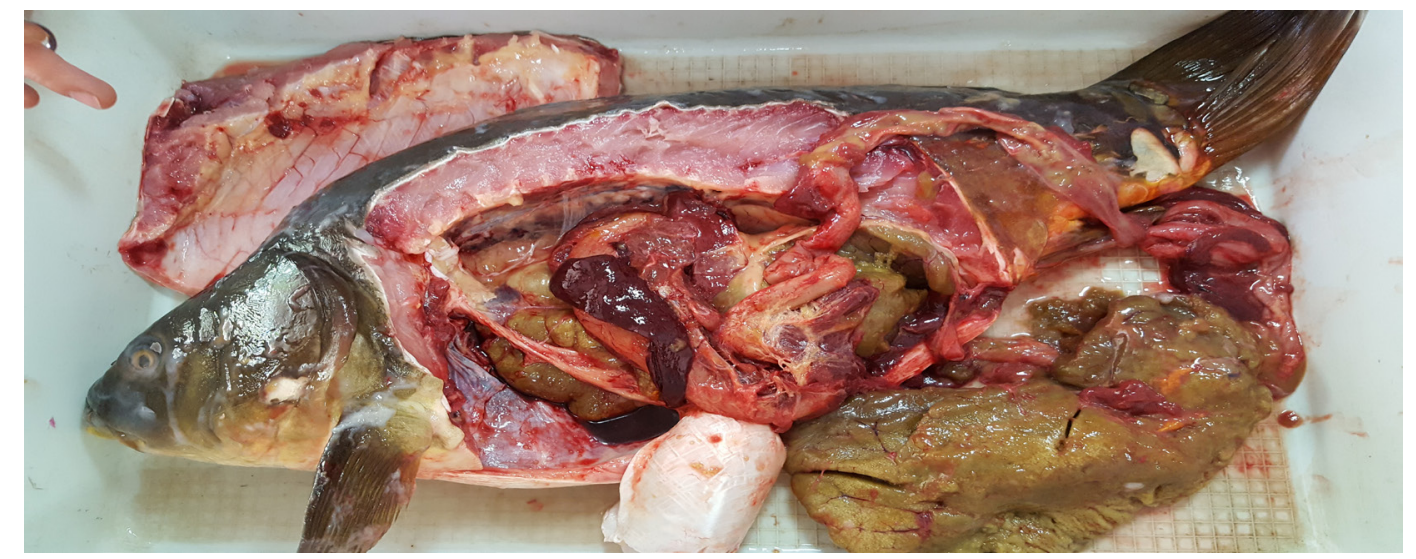

Fig. 2. Congestive and hemorrhagic lesions in muscles and internal organs

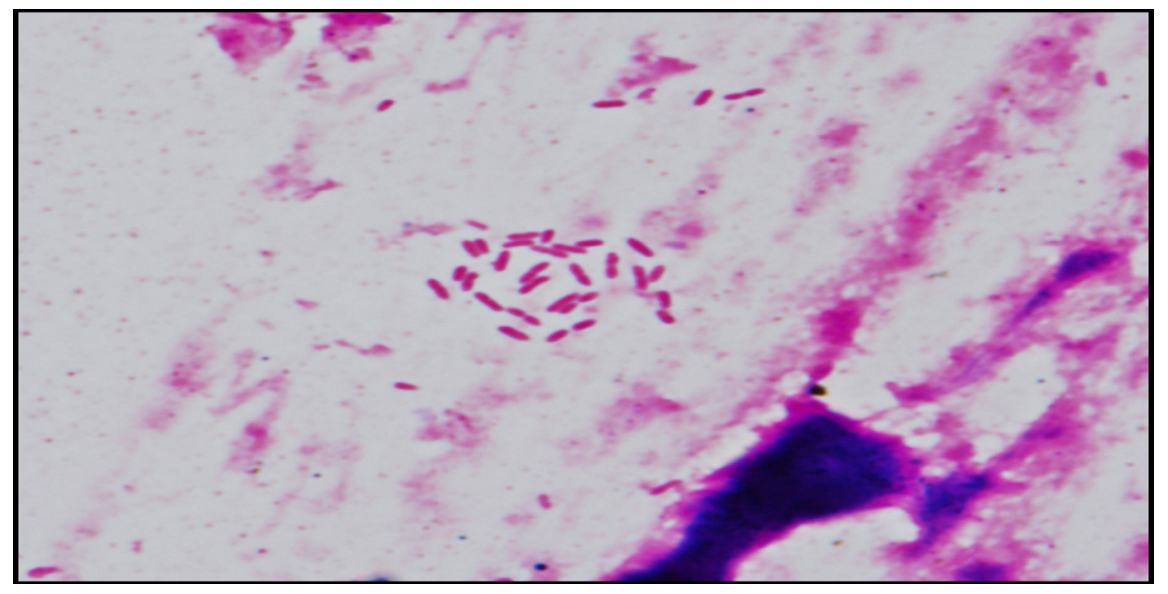

Fig. 3. A.hydrophila morphology in a carp skin sample, Gram stain 
group I, as it can be observed in. Fig 5. Similar findings were revealed previously by Joseph SW, ans Carnahan AM (1994).

After testing the sensitivity of the Aeromonas hydrophila strains challenged with different drugs by the antibiogram method (diffusimetric method) we noticed that the isolated strains of Aeromonas hydrophila from the analised outbreakwere sensitive, in an increasing order to the following antibiotics: amoxicilin, florfenicol,
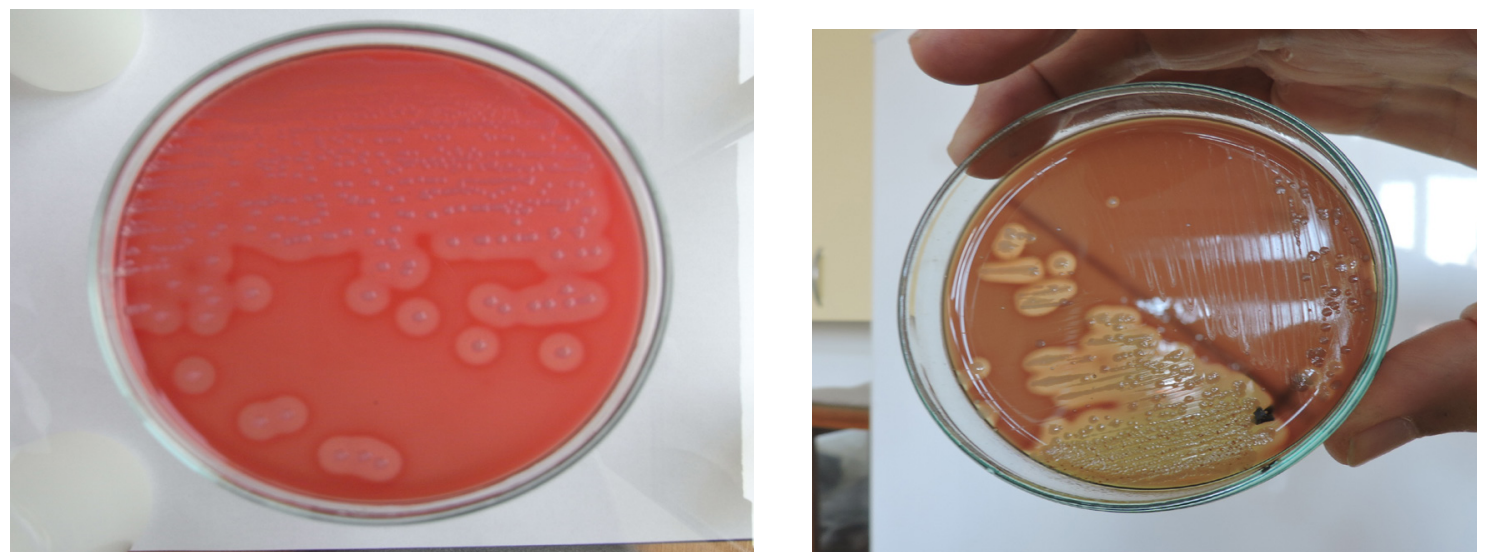

Fig 4 (a, b). Aeromonas hydrophila, on agar and serum culture revealing round, smooth and shiny collonies

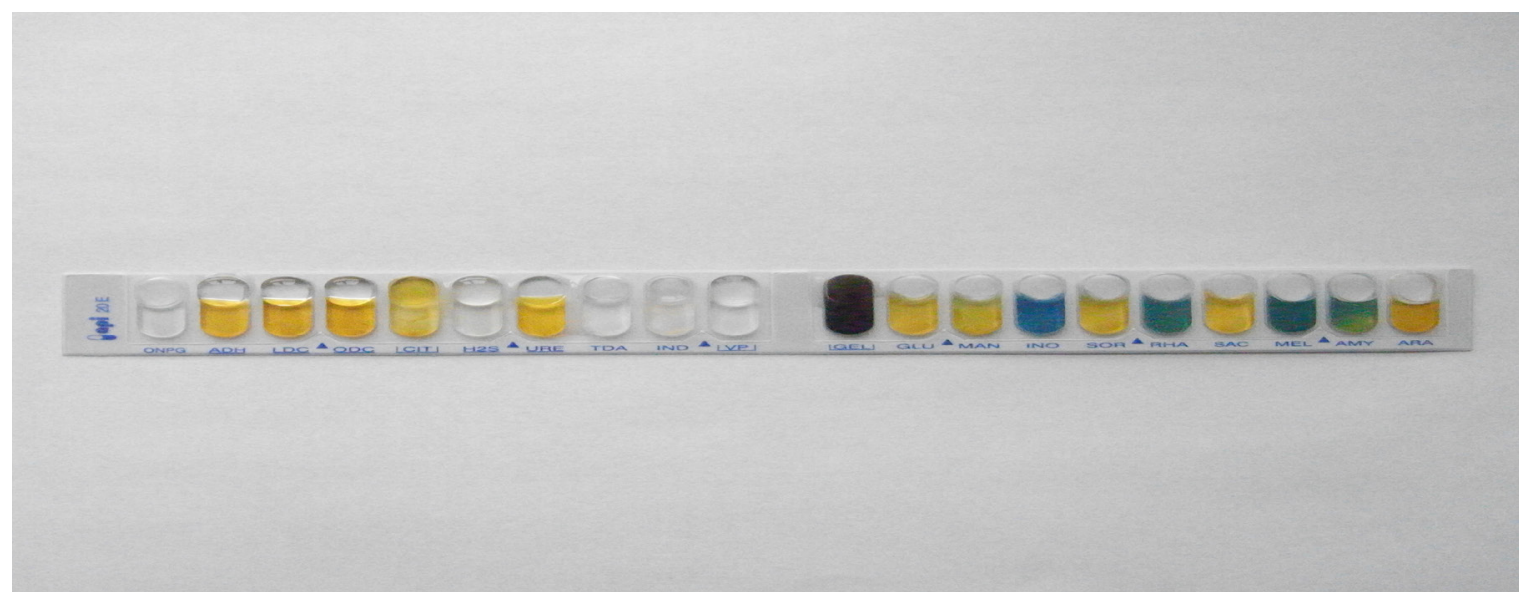

Fig 5. Positive biochemic reactions reveled by the multitest API 20 E system

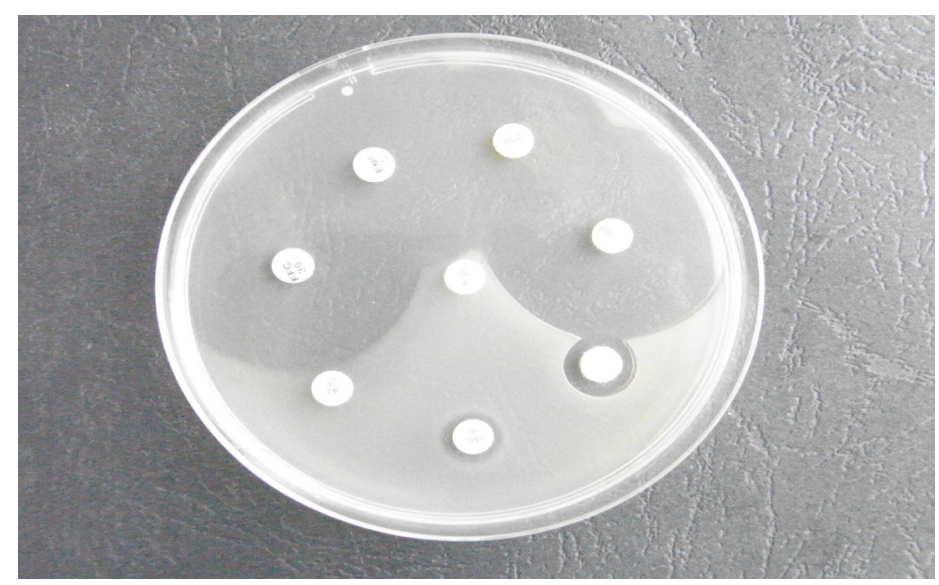

Fig.6. A. hydrophila sensibility test through antibiogram technique 
enrofloxacin, oxitetraciclin. The sensitivity of the bacterial strains was reduced under tetracilin while other strains were restistent at eritromicin and ampicilin.

\section{CONCLUSIONS}

The incidence of bacteriosis presented varried values depending on breeder's gender group, $54.8 \%$ in females and $36.3 \%$ in males.

The necropsy performed on 3 specimens with supposed bacteriosis revealed that the presence of hemoragic lesions on skin (diffuse or dotted) and necrosis of skin and muscles.

The bacterioscopic examination of smears from the pathologic material (skin surface end internal samples) and colored with the Gram method, reveled bacterial microflora, represented by coccobacillus and straight bacilli or slightly curved, both Gram negative.

The bacteriologic examination performed on normal and selective media revealed as well the isolation of the Aeromonas germs. The examination of biochemical traits, with the multitest system API 20 E showed that isolated germs of Aeromonas spp belong actually to the Aeromona hydrophila strain, incriminated for the appearance and evolution of the outbreak of bacterial hemorrhagic septicemia.
Testing the sensitivity to antibiotics and chemotherapy of the diagnosed strains reflects the followings:a) values of sensitivity for isolated bacteria were in ascending order: amoxicillin, oxytetracycline, florfenicol and enrofloxacilin, b) reduced sensitivity to tetracycline and c) resistant to ampicillin and erythromycin.

\section{REFERENCES}

1. Snieszko SF, Bullock GL (1976). Diseases of freshwater fishes caused by bacteria of the genera Aeromonas, Pseudomonas and Vibrio. US Dep Inter Fish and WildlServ Washington, DC FDL- 40: 1-10.

2. Austin B, Austin DA (2007). Bacterial Fish Pathogens: Disease in farmed and Wild Fish (4thEdn) SpringerPraxis,

3. Bohai X, Yin Zhan, Wu Yushen, Cai Taozhen (1993). Studies on the taxonomy of pathogenic bacteria of the bacterial hemorrhagic septicemia in cultured fishes in fresh water. Acta Hydrobiol Sinica 17: 259-266

4. Bud I, M Bura, A Bud, D Ladosi, A Totoian (2001). Peștii și tainele umbrelor subacvatice, Editura Ceres, București.

5. Dăscălescu P, Costea M (1995). Manual de diagnostic pentru bolile animalelor acvatice -Laboratorul Sanitar Veterinar de Diagnostic București.

6. Joseph SW, Carnahan AM (1994). The isolation, idendification and systematics of the motile Aeromonasspecies. Ann rev Fish Dis 45- 315-343

7. Negrea $O$ (2007). Bolile Peștilor- Editura Academic Pres, Cluj- Napoca. 